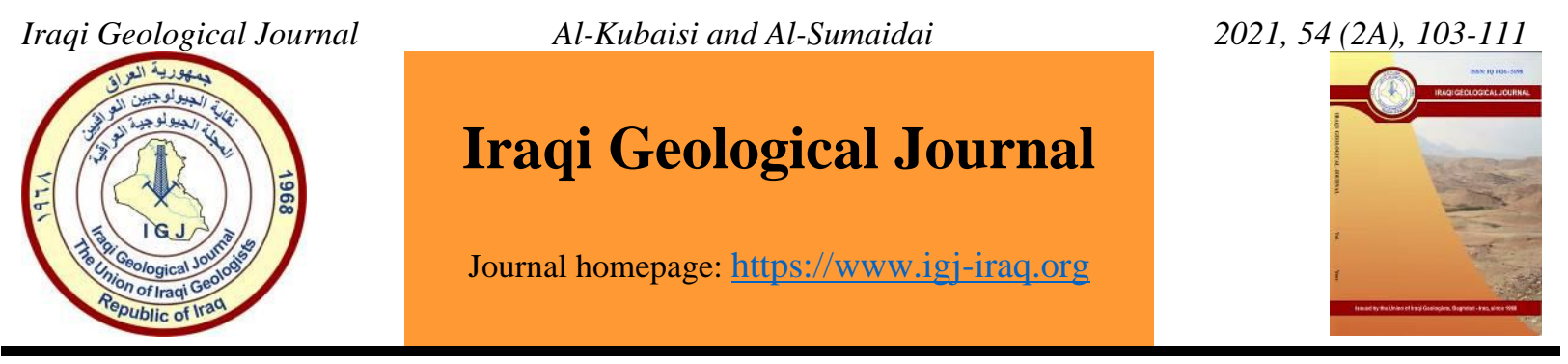

\title{
Hydrochemical Evaluation of Groundwater in Al-Khasfa Area within Haditha, Western Iraq
}

\author{
Qusai Y. Al-Kubaisi ${ }^{1}$ and Sufyan K. Al-Sumaidai ${ }^{1, *}$ \\ ${ }^{\mathbf{1}}$ Department of Geology, College of Science, University of Baghdad, Iraq \\ * Correspondence: Sfean989@gmail.com
}

Received: 10 February 2021; Accepted: 30 April 2021; Published: 31 July 2021

\begin{abstract}
The main aim of the research is to study the groundwater quality in Al-Khasfa area within Haditha district, western Iraq. To assess the groundwater, eighteen groundwater samples in the study area were collected and analyzed for major cations and anions. Results indicated that groundwater samples in the study area are between neutral and light alkaline, slightly brackish, and highly mineralized. The hydrochemical formula of the groundwater samples indicates the $\mathrm{Ca}-\mathrm{SO}_{4}$ type dominance, except wells number 16 and 17 were of $\mathrm{Ca}-\mathrm{Cl}$ water type. According to Piper diagram, the type of water is Earth-Alkaline waters. All groundwater samples are unsuitable for human drinking, industrial, and building uses, but it is suitable for livestock. For irrigation purposes, it is characterized by no Mg-harmful, good with SAR, Na\%, RSC, and PI but unsuitable for salinity hazard due to very high salinity. The Water Quality Index for Euphrates aquifer in the study area in both periods are poor water for human drinking, except W-1 in dry period indicate very poor water and W-6, W-7, W-8, $\mathrm{W}-13, \mathrm{~W}-14, \mathrm{~W}-15, \mathrm{~W}-16$ in wet period indicate good water.
\end{abstract}

Keywords: Groundwater; Piper diagram; Euphrates Aquifer; Water quality index

\section{Introduction}

Hydrochemical studies detect the quality of water in its chemical, physical and biological characteristics to obtain its suitability for human drinking, industrial and agriculture purposes (Al-Salih and Al-Kubaisi, 2016). The chemical composition of groundwater is influenced by several variables, including the lithological composition of the formation aquifer rocks, topography, precipitation and climate (Salar and Al-Kubaisi, 2009). The Hydrochemical of groundwater data gives evidence for the geologic history of rocks and shows the movement, recharge and storage of groundwater (Al-Sudani, 2019). Regional variations in water characteristics will result from variation of climate and geology and the most important factors related to irrigation and climate parameters (Awadh and Al-Kilabi, 2014). Water quality has an individual pattern of chemical and physical properties, which are determined largely by the geomorphological, climatic and geochemical conditions prevailing in the drainage basin and the underlying aquifer (Sen, 2015). 


\section{Study Area and Hydrogeological Setting}

The study area is located in the Western Desert $200 \mathrm{~km}$ away from Baghdad city in the northwest direction. It occupies almost $116 \mathrm{~km}^{2}$ with an elevation of 191-160 m above sea level, between latitudes $34^{\circ} 8^{\prime} 0^{\prime \prime}-34^{\circ} 12^{\prime} 40^{\prime \prime} \mathrm{E}$, and longitudes $42^{\circ} 8^{\prime} 0^{\prime \prime}-42^{\circ} 18^{\prime} 40^{\prime \prime} \mathrm{N}$. The area is bordered on the north by Haditha Lake (Fig.1). The study area is located on the stable platform (Rutba - Jazeera Zone). The area is relatively flat rises gradually and gently westwards. Geologically. The largest part of the study area covers the Euphrates Formation (Lower Miocene), which consists of carbonate rocks mainly of limestone, dolomitic limestone and marly limestone (Abdul-Razzak and Zaynal, 2016). The Fatha Formation (Middle Miocene), which consists mainly of evaporating facies layers of anhydrite and gypsum interbedded with marl and limestone (Al-Jiburi and Al-Basrawi, 2014). These formations are covered by Quaternary deposits (Pleistocene-Holocene) which consist of: residual soil and slope sediments (Jassim and Goff, 2006) (Fig. 2). The Euphrates Formation in the region represents the upper groundwater aquifer, which represents the groundwater discharge regions (Jummah and Al-Shammaa, 2020). The Euphrates aquifer is exposed along both sides of the Euphrates River and deeply cut valleys south of Euphrates River (Fig. 1) show the direction of groundwater flow for dry season (29-30 September 2019), the groundwater movement toward the Euphrates River, from the southwest to northeast and following the earth surface topography in the study area. The recharge supply of the aquifer is mostly from the rainfall and the underlying aquifer due to the hydraulic connection between them (Al-Jiburi and Al-Basrawi, 2014).

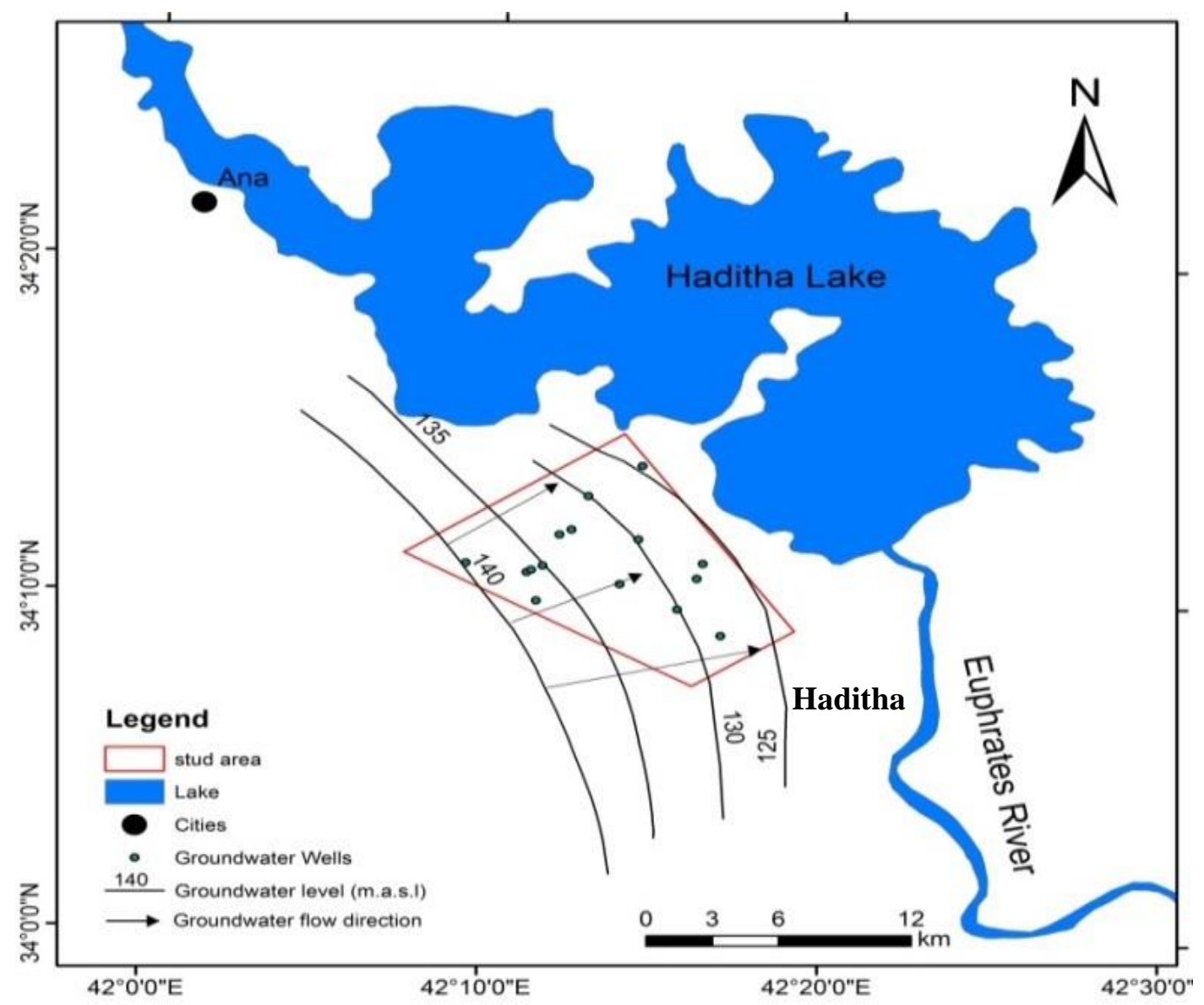

Fig. 1. Location map and groundwater flow of the studied area 


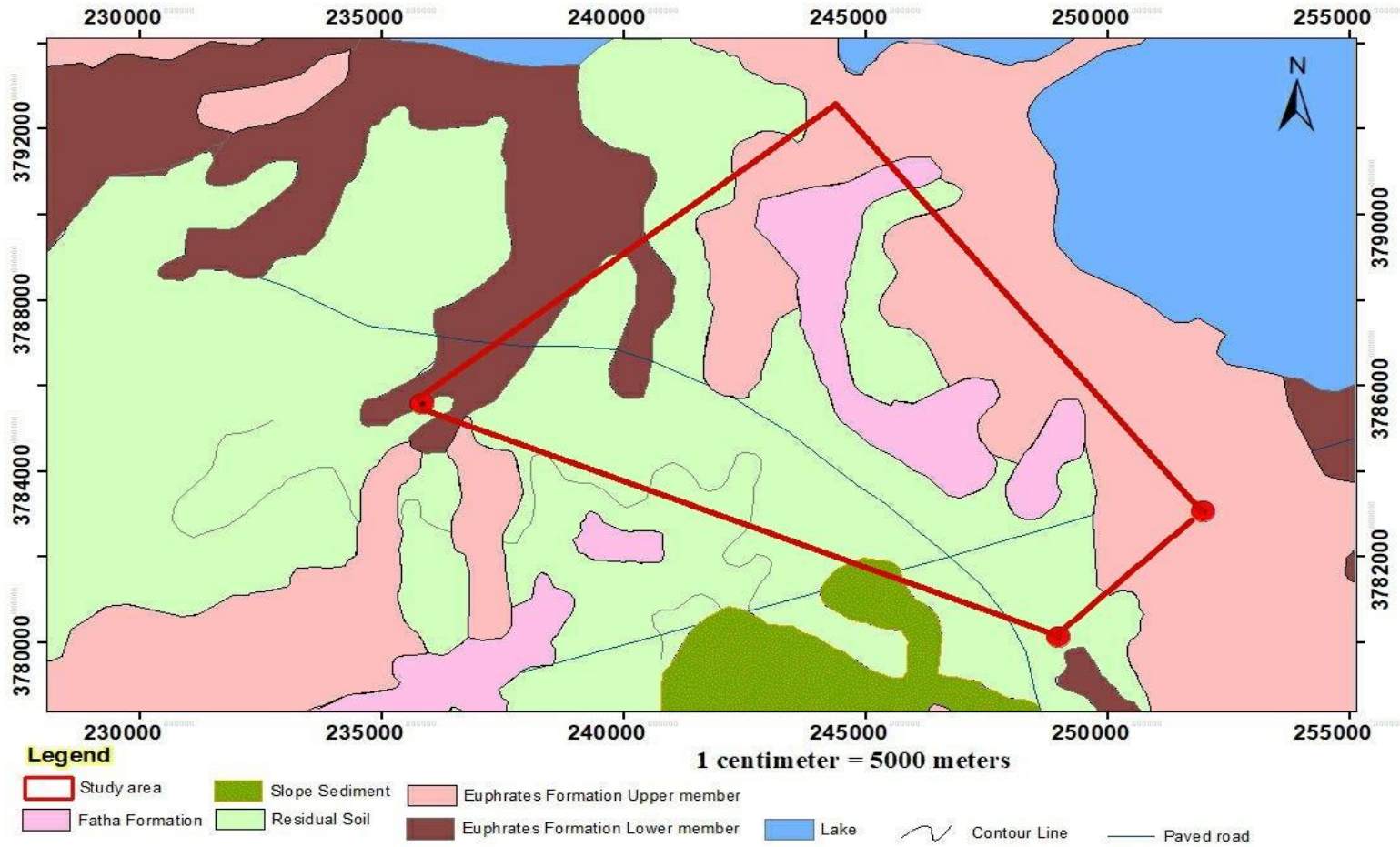

Fig. 2. Geological map of the studied area modified from (Sissakian and Qanber, 1993)

\section{Materials and Methods}

Eighteen groundwater sample were collected from the study area in the dry period (September, 2019) and wet period (April, 2020) (Fig.3). Total Dissolved Solids (TDS), water Temperature (T), Hydrogen Number $(\mathrm{pH})$, and Electrical conductivity (EC) were measured directly after taking the sample. Laboratory tests were analysed for the major ions. The chemical analyses of samples were carried out in the laboratory of General Commission for Groundwater using a standard procedure of APHA, (2005).

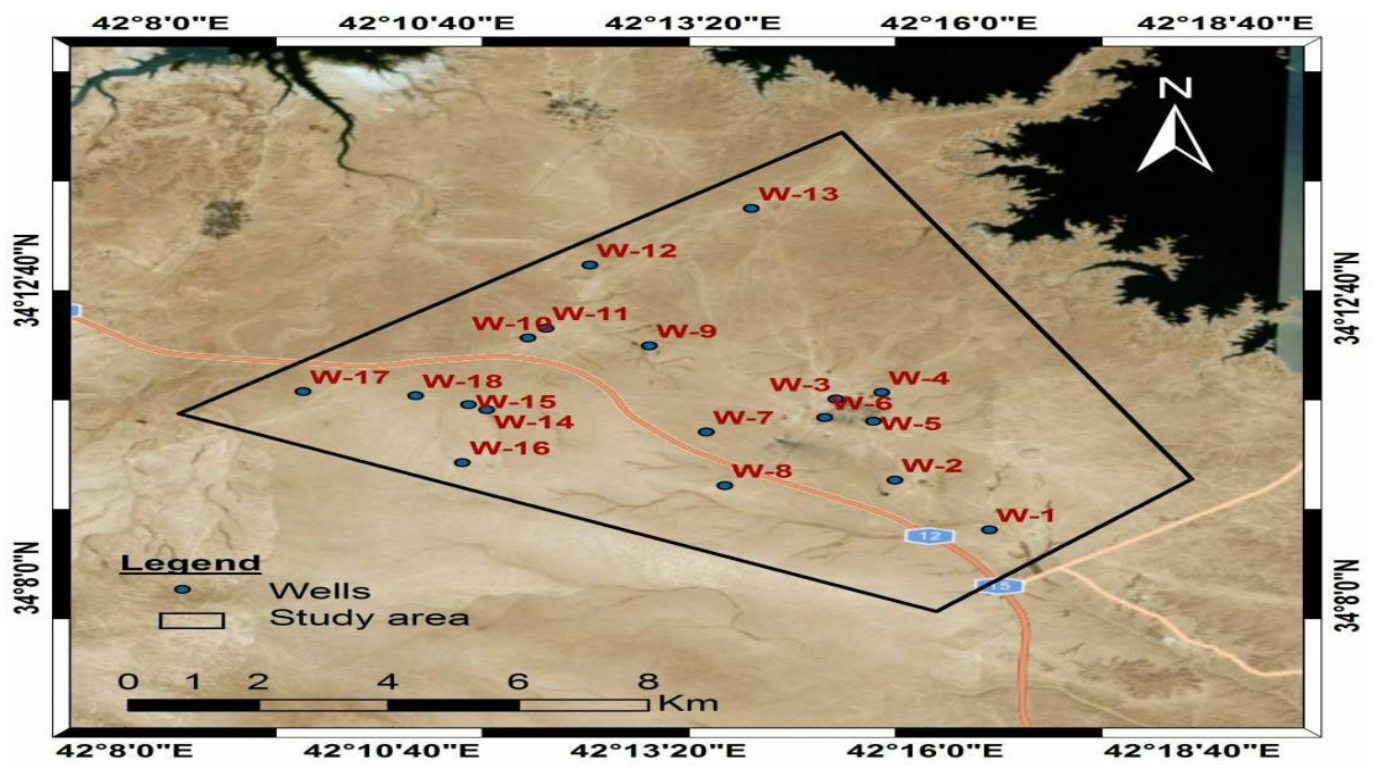

Fig. 3. Locations of the selected wells in the study area 


\section{Results and Discussion}

The physical characteristics of groundwater samples is shown in Table 1. Groundwater characterized in the study area as an odorless, colorless, as for the temperature ranged $\left(26-30{ }^{\circ} \mathrm{C}\right)$ with an average of $27.9^{\circ} \mathrm{C}$ for the dry season $\left(23-25.6^{\circ} \mathrm{C}\right)$ with an average of $24.2^{\circ} \mathrm{C}$ for the wet season. The ranges of $\mathrm{pH}$ value during dry season from $6.9-7.5$ with an average of 7.2. while a slight increase during wet season from $7-7.4$ with an average of 7.1. The ranges of EC value during dry season from 3963 to 7873.5 with an average of $4757 \mu \mathrm{S} / \mathrm{cm}$ while a slight decrease during wet season from 3338.37 to 6995.73 with an average of $4104.64 \mu \mathrm{S} / \mathrm{cm}$. The ranges of TDS value during dry season from 2649 to 5250 with an average of $3184.66 \mathrm{mg} / \mathrm{l}$ while a slight increase during wet season from 2289 - 4790 with an average of $2875.38 \mathrm{mg} / \mathrm{l}$. As mentioned before, the main geological water bearing formation in the area is the Euphrates which is of marine depositional environments. The increase in EC and TDS is generally due to solution of calcium carbonate deposits by groundwater. The results of hydrochemical analysis of the groundwater samples in the study area for the two seasons are shown in Tables 2 . The results show high concentrations of major ions where the cation $\mathrm{Ca}^{2+}$ is dominating while the anion $\mathrm{SO}_{4}{ }^{2-}$ is dominating in both seasons. Depending on the formula of Ivanov et al. (1968), all the groundwater samples are $\mathrm{Ca}$-Sulphate type, except samples number W.16 and W.17 where the water type is $\mathrm{Ca}-$ Chloride in two seasons. These results indicate the similarity of the hydrogeochemical processes. The availability of the calcium sulfate water type refers to the effect gypsum bed that exists in the Fatha Formation.

Table 1. Physical parameters of water samples in the two seasons

\begin{tabular}{lcccccccc}
\hline Well & \multicolumn{3}{c}{ Dry season (Sep.2019) } & \multicolumn{3}{c}{ Wet season (Apr. 2020) } \\
\hline & $\mathrm{T}\left({ }^{0} \mathrm{C}\right)$ & $\mathrm{pH}$ & $\mathrm{EC} \mu \mathrm{S} / \mathrm{cm}$ & $\mathrm{TDS} \mathrm{mg} / \mathrm{l}$ & $\mathrm{T}\left({ }^{0} \mathrm{C}\right)$ & $\mathrm{pH}$ & $\mathrm{EC} \mu \mathrm{S} / \mathrm{cm}$ & $\mathrm{TDS} \mathrm{mg} / \mathrm{l}$ \\
W.1 & 29 & 6.9 & 7873.5 & 5250 & 23.7 & 7 & 6995.73 & 4790 \\
W.2 & 27.5 & 7.1 & 6397.5 & 4270 & 25.6 & 7.3 & 5512.5 & 3800 \\
W.3 & 30 & 7.2 & 5365.5 & 3580 & 24.9 & 7.4 & 4646.67 & 3200 \\
W.4 & 28.4 & 7.1 & 5113.5 & 3410 & 25 & 7 & 4360.02 & 3000 \\
W.5 & 28.1 & 7.4 & 4786.5 & 3200 & 24.5 & 7.2 & 4135.11 & 2850 \\
W.6 & 27.5 & 7.2 & 4329 & 2890 & 24 & 7 & 3720.57 & 3545 \\
W.7 & 29 & 7.5 & 4111.5 & 2750 & 23.9 & 7.3 & 3560.34 & 2430 \\
W.8 & 30 & 7.3 & 3963 & 2650 & 24.6 & 7.2 & 3338.37 & 2300 \\
W.9 & 27 & 7.4 & 3966 & 2649 & 25 & 7.3 & 3339.84 & 2289 \\
W.10 & 29.2 & 7.1 & 4951.5 & 3350 & 24.3 & 7 & 4301.22 & 3021 \\
W.11 & 28.5 & 7.3 & 4660.5 & 3145 & 23.8 & 7.2 & 4138.05 & 2850 \\
W.12 & 28 & 7 & 4552.5 & 3050 & 23.2 & 7 & 3932.25 & 2700 \\
W.13 & 26.3 & 7.3 & 4074 & 2730 & 24.6 & 7.2 & 3582.39 & 2453 \\
W.14 & 27 & 7.1 & 4147.5 & 2770 & 24 & 7 & 3592.68 & 2451 \\
W.15 & 26 & 7.3 & 4261.5 & 2850 & 23.8 & 7.2 & 3573.57 & 2456 \\
W.16 & 28.4 & 7.3 & 4267.5 & 2855 & 23 & 7.2 & 3679.41 & 2510 \\
W.17 & 26.6 & 7.2 & 4419 & 2955 & 23.5 & 7.1 & 3724.98 & 2552 \\
W.18 & 26.1 & 7.4 & 4389 & 2970 & 24.2 & 7.3 & 3749.97 & 2560 \\
\hline
\end{tabular}

\subsection{Classification of Groundwater Samples}

Piper (1944) suggested a trilinear water-classification diagram. Analyzes are plotted based on the percentage of every cation and anion calculated presented in milli-equivalent per liter (meq /l). Piper diagram is hydrochemical classification to determine water types and quality in the study area indicates the water samples classified into class e which appears earth alkaline water with increase portion of alkali with prevailing chloride and sulfate. For the drawing of this diagram, Rock Ware version 1.1 
program was used to show the relative concentrations of the various ions in groundwater samples from the study area (Fig. 4).

Table 2. Chemical analysis of water samples in two seasons

\begin{tabular}{|c|c|c|c|c|c|c|c|c|}
\hline \multirow[t]{2}{*}{ Well No. } & \multicolumn{8}{|c|}{ In dry season (ppm) } \\
\hline & $\mathrm{Ca}^{2+}$ & $\mathbf{N a}^{+}$ & $\mathbf{M g}^{2+}$ & $\mathbf{K}^{+}$ & $\mathrm{SO}_{4}{ }^{2-}$ & $\mathrm{Cl}^{-}$ & $\mathrm{HCO}_{3}{ }^{-}$ & WQI \\
\hline W.1 & 800 & 543 & 234 & 27 & 2456 & 845 & 344 & 207.35 \\
\hline W.2 & 645 & 453 & 200 & 18 & 1987 & 510 & 452 & 155.65 \\
\hline W.3 & 567 & 412 & 134 & 21 & 1423 & 600 & 420 & 153.21 \\
\hline W.4 & 523 & 400 & 125 & 24 & 1289 & 634 & 414 & 158.80 \\
\hline W.5 & 540 & 378 & 145 & 23 & 1287 & 623 & 395 & 161.48 \\
\hline W.6 & 440 & 345 & 112 & 16 & 998 & 567 & 408 & 116.88 \\
\hline W.7 & 411 & 350 & 96 & 18 & 860 & 578 & 428 & 127.55 \\
\hline W.8 & 412 & 300 & 97 & 16 & 855 & 556 & 406 & 118.84 \\
\hline W.9 & 401 & 321 & 98 & 24 & 860 & 567 & 373 & 148.20 \\
\hline W.10 & 560 & 321 & 99 & 20 & 1420 & 543 & 338 & 138.91 \\
\hline W.11 & 460 & 345 & 150 & 25 & 999 & 700 & 428 & 163.12 \\
\hline W.12 & 450 & 378 & 112 & 22 & 967 & 654 & 452 & 139.51 \\
\hline W.13 & 400 & 312 & 89 & 17 & 865 & 545 & 463 & 120.60 \\
\hline W.14 & 412 & 323 & 88 & 19 & 940 & 543 & 440 & 121.80 \\
\hline W.15 & 423 & 344 & 83 & 18 & 890 & 556 & 527 & 123.64 \\
\hline W.16 & 430 & 367 & 77 & 18 & 865 & 645 & 443 & 125.89 \\
\hline W.17 & 402 & 389 & 132 & 20 & 879 & 654 & 470 & 137.30 \\
\hline W.18 & 400 & 367 & 98 & 17 & 1115 & 444 & 485 & 123.19 \\
\hline Well No. & \multicolumn{8}{|c|}{ In wet season (ppm) } \\
\hline W.1 & 740 & 498 & 203 & 21 & 2234 & 770 & 293 & 177.5 \\
\hline W.2 & 590 & 402 & 180 & 13 & 1812 & 443 & 310 & 134.85 \\
\hline W.3 & 512 & 378 & 113 & 14 & 1323 & 525 & 296 & $125 . .68$ \\
\hline W.4 & 487 & 350 & 105 & 17 & 1100 & 560 & 347 & 123.12 \\
\hline W.5 & 450 & 311 & 113 & 18 & 990 & 560 & 371 & 125.23 \\
\hline W.6 & 388 & 300 & 99 & 11 & 889 & 475 & 369 & 87.55 \\
\hline W.7 & 367 & 298 & 89 & 12 & 754 & 500 & 402 & 95.65 \\
\hline W.8 & 356 & 245 & 80 & 10 & 723 & 480 & 377 & 86.83 \\
\hline W.9 & 345 & 289 & 82 & 17 & 722 & 475 & 342 & 112.49 \\
\hline W.10 & 501 & 287 & 81 & 15 & 1280 & 450 & 312 & 109.7 \\
\hline W.11 & 467 & 295 & 113 & 18 & 889 & 632 & 401 & 127.79 \\
\hline W.12 & 390 & 324 & 100 & 16 & 878 & 643 & 324 & 110.48 \\
\hline W.13 & 360 & 278 & 95 & 12 & 834 & 443 & 415 & 96.22 \\
\hline W.14 & 367 & 299 & 76 & 14 & 812 & 453 & 423 & 94.61 \\
\hline W.15 & 369 & 289 & 65 & 14 & 756 & 461 & 477 & 98.21 \\
\hline W.16 & 387 & 312 & 77 & 13 & 732 & 565 & 417 & 99.83 \\
\hline W.17 & 356 & 334 & 93 & 16 & 743 & 549 & 443 & 108.93 \\
\hline W.18 & 378 & 289 & 79 & 14 & 978 & 378 & 435 & 103.16 \\
\hline
\end{tabular}



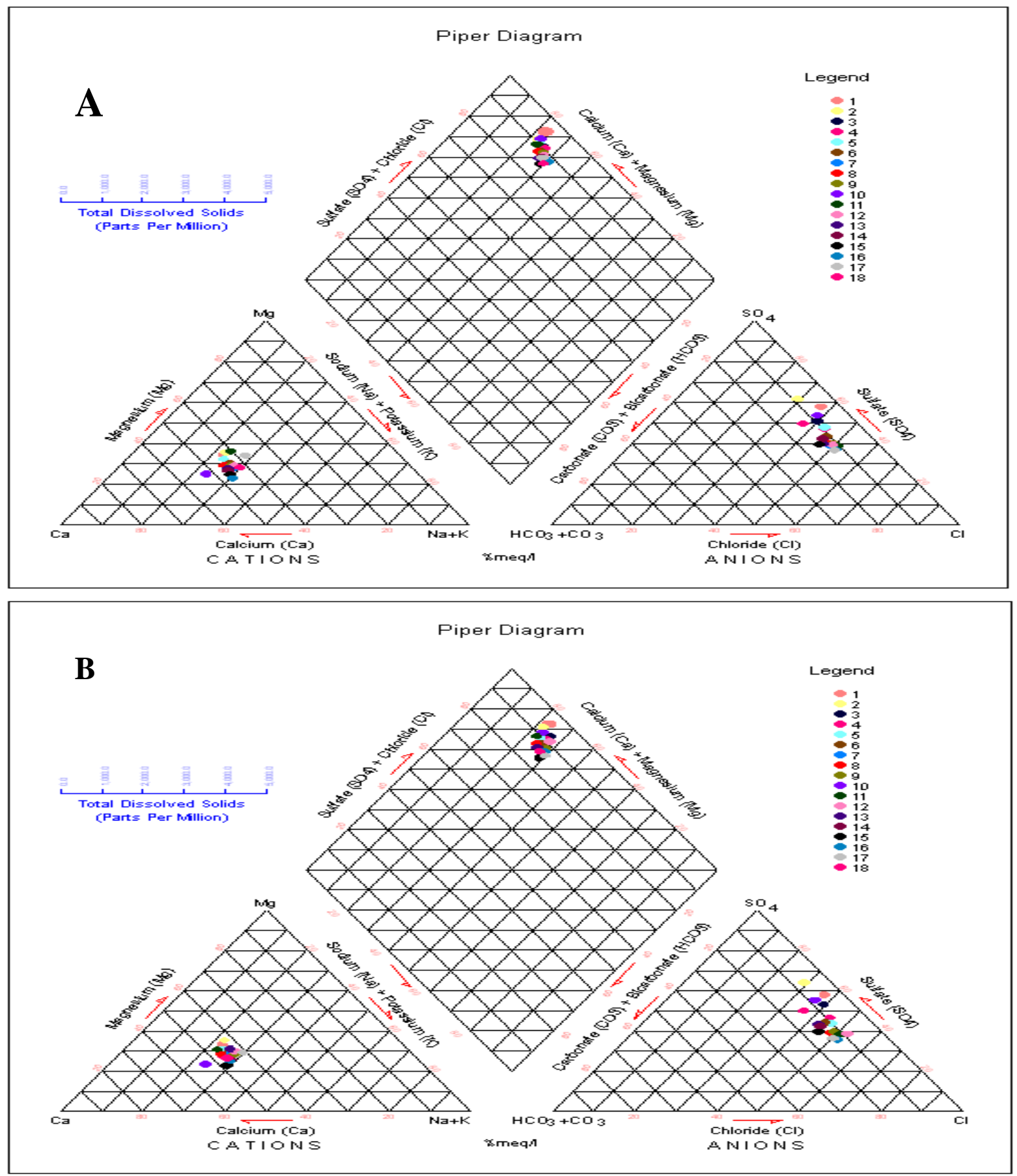

Fig. 4. Type of water according Piper, (1944). A) In dry season; B) in wet season

\subsection{Drinking-Water Quality Index (WQI)}

WQI is an important method for demarcating the quality of groundwater and its suitability for human consumption (Rashid, et al., 2016). WQI is a mathematical instrument used to converting large quantities of water quality data into single number which represents water quality level. The WQI gives a general idea of water problems in any area, so it is considered is a primary indicator of water quality (Al-Kubaisi, 2020). In this study chemical parameters TDS, pH, Calcium, Sodium, Magnesium, Potassium, Sulfate, Chloride and Nitrate ions have been used for assessment of groundwater suitability for drinking purposes to develop WQI model. For calculation of WQI model, the standards for drinking purposes, as recommended by World Health, Organization Standard (WHO, 2011). The WQI for all 
groundwater samples in dry period are poor water for human drinking, except $\mathrm{W} 1$ is very poor water for human drinking. While the WQI for all groundwater samples in wet period are Poor water for human drinking, except W6, W7, W8, W 13, W14, W15, and W16 is good water for human drinking According to Vasanthavigar et al., (2010), (Table 2) and (Fig 5).
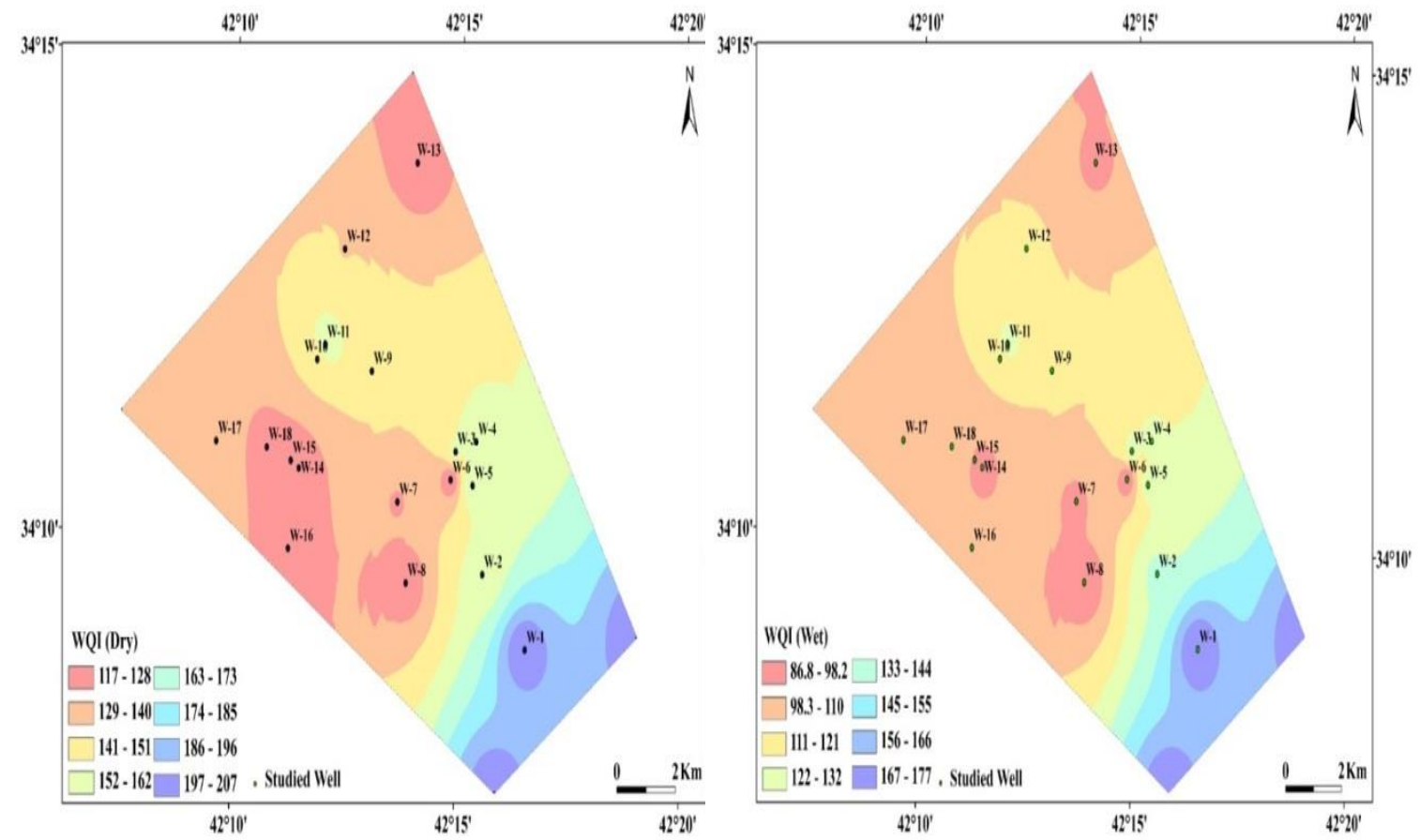

Fig. 5. WQI classification for groundwater in the study area in two periods

\subsection{Groundwater Uses}

According to IQS (2009) and WHO (2007) indicating the groundwater samples for two seasons was unsuitable for human drinking to most parameters. Groundwater samples compared with these specifications is found to be between very good water to good water for animal drinking in two seasons. The comparison of the groundwater samples with the standards is suggested by Hem, (1991) shows unsuitability of water in study area for all industrial purposes in two seasons. Groundwater water samples are unsuitable for building, because $\mathrm{Ca}^{+2}$ and $\mathrm{HCO}_{3}{ }^{-}$concentrations in two seasons exceed the recommended limit. To evaluate water quality for irrigation, there are several most popular criteria, these are: salinity hazard, sodium percentage (Na \%), sodium adsorption ratio (SAR), residual sodium carbonate (RSC) and permeability index (PI), (Table 3). The salinity hazard in groundwater samples in the study area for two seasons was very high saline (C4) in all wells according to Turgeon, (2000). While based on Don (1995) classification of irrigation water, according to $\mathrm{Na} \%$ values, the groundwater samples in the study area is good irrigation water class in two seasons. Wilcox, (1948) Has classified water for irrigation water depends on SAR values, where the samples showed that they are located within S1 (Use on sodium sensitive crops) in two seasons. Whereas, classification of irrigation water based on RSC values, groundwater samples in the study area are good and non-hazard category in two seasons according to Turgeon, (2000). On the other hand, permeability index (PI) was good quality for irrigation purposes in two seasons according to Nagaraju et al., (2006). 
Table 3. The calculated values of SAR, Na\%, RSC and PI of samples

\begin{tabular}{ccccccccc}
\hline Well & \multicolumn{3}{c}{ Dry season (Sep.2019) } & \multicolumn{3}{c}{ Wet season (Apr. 2020) } \\
\hline & SAR & Na\% & RSC & PI & SAR & Na\% & RSC & PI \\
W.1 & 4.32 & 28.99 & -53.85 & 31.25 & 4.17 & 29.15 & -49.1 & 31.55 \\
W.2 & 3.98 & 29.18 & -41.49 & 32.67 & 3.70 & 28.58 & -39.42 & 31.82 \\
W.3 & 4.02 & 31.83 & -32.63 & 35.75 & 3.92 & 32.41 & -30.16 & 36.22 \\
W.4 & 4.06 & 32.99 & -29.77 & 37.06 & 3.74 & 32.10 & -27.42 & 36.41 \\
W.5 & 3.71 & 30.34 & -32.6 & 34.18 & 3.38 & 30.46 & -25.83 & 35.18 \\
W.6 & 3.78 & 32.96 & -24.64 & 37.95 & 3.50 & 32.52 & -21.6 & 38.09 \\
W.7 & 4.02 & 35.44 & -21.54 & 40.80 & 3.60 & 33.98 & -19.18 & 40.08 \\
W.8 & 3.44 & 31.92 & -22.03 & 37.43 & 3.04 & 30.83 & -18.28 & 37.41 \\
W.9 & 3.71 & 34.05 & -22.1 & 38.95 & 3.62 & 35.05 & -18.48 & 40.73 \\
W.10 & 3.27 & 28.52 & -30.71 & 32.47 & 3.12 & 28.79 & -26.68 & 33.27 \\
W.11 & 3.56 & 30.58 & -28.49 & 34.94 & 3.16 & 28.85 & -26.19 & 33.74 \\
W.12 & 4.11 & 34.81 & -24.42 & 39.68 & 3.77 & 34.24 & -22.52 & 39.09 \\
W.13 & 3.66 & 33.80 & -19.82 & 39.82 & 3.35 & 32.35 & -19.11 & 38.66 \\
W.14 & 3.75 & 34.21 & -20.72 & 39.85 & 3.70 & 35.11 & -17.75 & 41.48 \\
W.15 & 3.99 & 35.45 & -19.42 & 41.59 & 3.63 & 35.12 & -16.05 & 42.15 \\
W.16 & 4.27 & 37.03 & -20.65 & 42.50 & 3.77 & 35.03 & -18.92 & 41.13 \\
W.17 & 4.28 & 35.91 & -23.39 & 41.005 & 4.06 & 36.88 & -18.29 & 42.96 \\
W.18 & 4.25 & 36.78 & -20.21 & 42.55 & 3.52 & 33.65 & -18.35 & 40.03 \\
\hline
\end{tabular}

\section{Conclusions}

- The Euphrates Formation is considered the main aquifer in the study area. Groundwater moves from the southwest to the northeast, towards the Euphrates River.

- Groundwater in the study areas is dominated by calcium and sulphate ions due to the carbonate dissolution of the Euphrates Formation.

- The type of groundwater samples area is Ca-sulphate type, except samples number W.16 and W.17 where the water type is Ca-chloride in both seasons refers to the effect gypsum bed that exists in the Fatha Formation.

- Piper diagram classified the type of groundwater as Earth-Alkaline waters.

- All groundwater samples are unsuitable for human drinking, industrial and building purposes.

- All groundwater samples are suitable for livestock uses.

- The suitability for irrigation purposes for the study area is characterized by no Mg-harmful, good with SAR, Na\%, RSC and PI but unsuitable for salinity hazard (EC and TDS) due to very high salinity.

- The WQI indicates that groundwater samples are poor water for human drinking, except W-1 in dry period indicate vary poor water and $\mathrm{W}-6, \mathrm{~W}-7, \mathrm{~W}-8, \mathrm{~W}-13, \mathrm{~W}-14, \mathrm{~W}-15, \mathrm{~W}-16$ ) in wet period indicate good water.

\section{Acknowledgements}

The authors are very grateful to the Editor in Chief Prof. Dr. Salih M. Awadh, the Secretary of Journal Mr. Samir R. Hijab, and the Technical Editors for their great efforts and valuable comments. 


\section{References}

Abdul-Razzak, M. I., and Zaynal, M. S., 2016. The simultaneous use of EM conductivity and radium resistivity techniques in solution channel detection. Iraqi Geological Journal, 61-72.

Al-Jiburi, H. and Al-Basrawi, N., 2014. Hydrogeological and hydrochemical study of Haditha Quadrangle (N1-38-5). GEOSURV Library, Rep. No. 3528.

Al-Kubaisi, M. H., 2020. Hydrochemical facies description to assess the water quality of Habbaniya Lake, Iraq. Iraqi Geological Journal, 94-107.

Al-Salih, S. A., \& Al-Kubaisi, Q. Y., 2016. Hydrochemical assessment of water resources in Al- Teeb area, NE Maissan governorate, south Iraq. Iraqi Bulletin of Geology and Mining, 12(2), 1-12.

Al-Sudani, H. I. Z., 2019. Hydrochemistry of groundwater in northeast part of Anbar Governorate, West of Iraq. Baghdad Science Journal, 16(1), 0088-0088.

APHA, 2005. Standard method for the examination of water and waste water, 21st ed. American public health Association, Washington, D.C.

Awadh, S. M., and Al-Kilabi, J. A. H., 2014. Assessment of groundwater in Al-Hawija (Kirkuk Governorate) for irrigation purposes. Iraqi Journal of Science, 55(2Supplement), 760-769.

Don, C.M., 1995. A grows guide to water quality. University college station, Texas.

Hem, J. D., 1991. Study and interpretation of the chemical characteristics of natural water. USGS. Water Supply paper no. 2254, $263 \mathrm{P}$.

IQS, Iraqi Standard, 2009. Iraqi Standard of Drinking Water No. 417, Second modification.

Ivanov, V. V., Barbanov, L. N., and Plotnikova G. N., 1968. The main genetic types of the earth's crust mineral water and their distribution in the USSR, Inter. Geol. Cong. of 23rd. Sessions, Czechoslovakia, 12, 33.

Jassim, S.Z. and Goff, J.C., 2006. Geology of Iraq, Dolin Prague and Moravian Museum, Brno, 341 pp.

Jummah, M. S., and Al-Shammaa, A. M., 2020. Hydrochemical assessment of groundwater of Euphrates aquifer in Anah, Western Iraq for irrigation purposes. Iraqi Geological Journal, 121-133.

Nagaraju, A., Suresh, S., Killhan, K., and Hudson-Edwards,K., 2006. Hydrogeochemistry of waters of management barite mining area, Cuddapah Basin, Andhra Pradesh, India. Turkish Journal of Engineering Sciences, 30, 203-219.

Piper, A. M., 1944. A graphic procedure in the geochemical interpretation of water-analyses. Eos, Transactions American Geophysical Union, 25(6), 914-928.

Rashid, A. A., Al-Dabbas, M. A., and Kadhim, W. H., 2016. Assessment of groundwater quality for drinking in Tuz Khurmatu area, Salahadden Governorate, Iraq. The Iraqi Geological Journal, 91-103.

Salar, S. G., and Al-Kubaisi, Q. Y., 2009. Hydrochemical evaluation of the groundwater in Fatah Umar_Hazar Kani area, Northeast Iraq. Iraqi Bulletin of Geology and Mining, 5(1), 87-99.

Sen, A. Z. 2015. Practical and Applied Hydrogeology, Elsevier, Inc. First edition, 407pp.

Sissakian, V. K., and Qanber, S. H., 1993. Geological Map of Haditha Quadrangle, scale 1:250000. Iraq Geological Survey Publications, Baghdad, Iraq.

Turgeon, A. J., 2000. Irrigation Water Quality, College of Agricultural sciences The Pennsylvania State University, USA.

Vasanthavigar, M., Srinivasamoorthy, K., Ganthi, R. R., Vijayaraghavan, K., \& Sarma, V. S., 2012. Characterization and quality assessment of groundwater with a special emphasis on irrigation utility: Thirumanimuttar sub-basin, Tamil Nadu, India. Arabian journal of Geosciences, 5(2), 245-258.

Wilcox, L.V., 1948. Classification and Use of Irrigation Waters. Department of Agriculture, United States, Circular No. 696, Washington D.C., 16.

World Health Organization (WHO), 2007. Guide fine for drinking water quality Recommendation,.4th ed., 36. World Health Organization (WHO), 2011. Guideline for drinking water quality, 4th ed., Geneva, 564. 